\title{
Exotic Spice Illicium Verum Hook.F
}

\begin{abstract}
Hafiza Touseef Sayyar
ABSTRACT

Chinese Star anise (Illicium verum hook.f.) spice is generally consumed in food, beverages and confectionery item due to their characteristic spiciness as well as zesty flavor. Star anise is extensively employed in Chinese traditional medicine and as a tonic for home remedies since ancient times for many complaints such as gastrointestinal disorder, colic discomfort and inflammation. The active components present in star anise has been identified by many researchers and several favorable, pharmacological effects of its constituents confirmed and authenticated recently by experiment. Additionally, many studies reveal numerous health effects of this spice. This article concisely reviews the most noticeable investigations which have validated the potential of star anise such as anxiolytic, anti-microbial, antioxidant, chemopreventive, insecticidal, flu prevention, atherogenesis, lactagouge, anticolic action. However star anise is usually nontoxic and used as a functional ingredient of daily cuisine.
\end{abstract}

Keywords: Star anise, Pharmacological effects, Anti-spasmodic, Anxiolytic, Lactagouge, Nutraceuticals, Anti-microbial, anti-Inflammmatory, Anticancer.

\section{INTRODUCTION}

Illicium verum Hook. f belongs to the family (Austrobaileyales: Schisandraceae) ${ }^{1}$; is a medium-sized native evergreen tree of Northeast Vietnam and South West China ${ }^{2}$ formerly allocated in the tropic and subtropics areas of Asia and utilized as a traditional medicine in East $\mathrm{Asia}^{3}$. The genus name is derived from Latin 'illicere' (allure), probably because of the sweet and pleasant fragrance. In 2002, Ministry Health of People's Republic China confirmed that star anise one of the item act as "both food and medicine".

Star Anise (Illicium verum Hook. f) is prehistoric spice, recocnized in China as far back as 100 B.C ${ }^{5}$. However traditionally Japanese use star anise plant and their bark as incense to produce perfumed smoke on their temples and on tombs. Seventh centuries recipes disclosed that this spice also used to prepare Jam and syrup ${ }^{6}$. Star anise flavor is oftnely mixed up with licorice and depict as a"licorice like" flavor ${ }^{7}$. In Europe fruit of star anise used as a liquer to prepare tincture and distillate ${ }^{8}$. In Chinese cusin star anise play important role they use it in seasoning dishes especially sweet dishes and to enhance the flavor of coffee and tea?

\section{METHODOLOGY}

A comprehensive literature search was being conducted from 1993-2017.the search engines utilized were Google Scholar, Pub Med, Springer link and Med line. In this review keyword of history plant description, chemical constituent, traditional use and pharmacological properties of spice Chinese star anise (Illicium verum Hook.f) were used and

I Hafiza Touseef Sayyar
I Pharmacist, Department of Pharmacology
I Bahria University Medical \& Dental College
Karachi
Email: touseef_sayyar@yahoo.com
| |
Received: 24-05-18
Iccepted: 11-07-18

45 articles of Asian and Pakistani literature are selected for write up.

\section{LITERATURE REVIEW:}

\section{a) Origin of the Name:}

The generic name of star anise (Illicium verum Hook. f) originated from Latin word "Illicio" or "Illicere" which means to attract or the fragrance ${ }^{10}$.

\section{b) Local Names:}

Star anise recognized by many substitutes' names according to the origin of specific regions. In China it is known as a "Ba Jiao Hui Xiang". Following are other synonyms by the other countries ${ }^{11}$.

English Name: Star anise

Danish: Stjerne Anis

Dutch: Adas china, Steranijs

French: Anis de la Chine, Badiane

German: Badian, Sternanis

Indonesian: Adas cina, bunga lawang, Pe ka

Italian: Anice Stellato

Khmer: Phka Cann, Poch kak lavhak, Innish Tähtianis

Portuguese: Anis Estrelado

Spanish: Anís Estrellado

Thai: Dok chan, poy kak bua

Vietnamese: vat giac huong, dai hoi, hoi sao, mai, cay hoy In Hindi and Urdu its commonly known by "Badiyan $\mathrm{Ka}$ Phool" (Badayan, Anasphal) ${ }^{12}$.

\section{c) Plant Description:}

Illicium verum hook.f (Figure-1) medium sized evergreen plant having $8-15 \mathrm{~m}$ height and equal to $30 \mathrm{~cm}$ in $\mathrm{dbh}$ along with green, glabrous branches on straight rounded stem. The bark is white to bright grey in color. The plant of this spice is proliferated by seed and generally planted for fragrance, medicine and culinary purposes in southern china and Vietnam. The fruit of this spice is colle cted before they ripen and then sun dried. The flowers are grow from March 
to May and fruits are ripen from September to October ${ }^{13,14}$.

\section{d) Traditional Uses of Star Anise in Medicine:}

Nearly seventeenth century European firstly introduces Star anise spice having specific licorice type taste due to the presence of chemical constituent anethole ${ }^{15}$. In 1505 's book
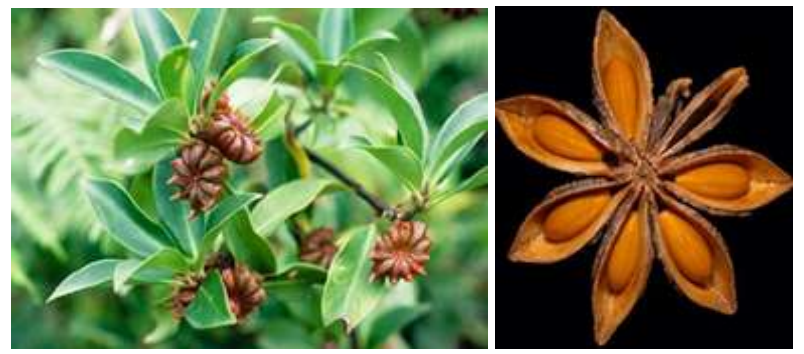

Fig: 1 (Illicium verum hook.f)

of "Herbal Essentials Collection" stated that Illicium verum is used for the cure of cholera and fistula. In 1769 HUANG Gongxiu discovered that spice star anise is used to prevent chronic $^{16}$. It was documented in book "Herbal positive" I.verum play a vital role to eliminate teeth and mouth disease. It is used as a common flavoring agent in coffee and tea, lozenges and cough syrups, stimulant, expectorant and diuretic. Star anise oil has beneficial effects in the treatment of rheumatism and lower back pain and possesses anti- oxidants properties due to presence of Linalool ${ }^{17,18}$.

Star anise has a long history being consumed in Chinese traditional cooking and medicine for the treatment of skin inflammation, vomiting, stomachaches, rheumatic and sleeplessness ${ }^{19}$. Essential oil of I.verum contain approximately $70-90 \%$ anethole, having estogenic properties thus it is used to relief from rheumatism and lower back pain ${ }^{20}$. It has a good carminative property for that reason it is often chew up in minute amounts after each meal to stimulate digestion and helps to relieve flatulence. This spice is used in several preparations which is intended for both external and internal application. The most common internal use of this spice is for dyspeptic complain on the other hand topically it is implemented as an inhalant for the respiratory tract congestion. It is also a chief constituent of anti-tussives remedies and currently employ as a flu medicine. However, large quantity of this spice can cause neurotoxic effects ${ }^{21}$.

\section{Chemical constituents of Star Anise:}

Chinese star anise contains numerous numbers of chemical constituents having various pharmacological actions ${ }^{22,23}$, few of them are mentioned below

\section{Culinary usage of star anise:}

Illicium verum as an essential spice and main constituent of Chinese, Malay and Indonesian cuisines ${ }^{24}$. In Asian cuisines

\begin{tabular}{|l|l|}
\hline \multicolumn{1}{|c|}{ COMPOUND } & \multicolumn{1}{c|}{ PHARMACOLOGICAL ACTION } \\
\hline Anethole & Antimicrobial,Antifungal and Insecticidal \\
\hline Anisaldehyde & Fragrance, scent of licorice. \\
\hline Beta-caryophyllene & Anti-inflammatory, Anti-nociceptive, Neuroprotective \\
\hline Benzoic acid-4-beta-d-glucoside & Antifungal \\
\hline Cinnamic acid & Flavoring agent \\
\hline Cinnamaldehyde & Fungicide, Insecticide \\
\hline Cinnamyl alcohol & Sensitizing agent \\
\hline Caffeic acid & Antioxidant and Anti-inflammatory \\
\hline Cineol & Mouthwash,cough suppressant, Insecticide and repellent \\
\hline Citronellol & Perfumery and Insect repellents \\
\hline Estragole & Perfumes and food additive for flavor \\
\hline Eugenol methyl ether & Perfumes, flavorings,local antiseptic and anesthetic. \\
\hline Kaempferol & Antioxidant \\
\hline Kaempferol-3-o-beta-d-rutinoside & Flavonol glycoside \\
\hline Lignans & Anticarcinogenic, Anti-inflammatory \\
\hline Myrcene & Perfumery agent \\
\hline P-methoxy-cinnamaldehyde & Fungicide \\
\hline P-coumaric acid & Antioxidant and Anticancer \\
\hline Phenylpropanoids & Defensive agent against herbivores and pathogens \\
\hline P-methoxycinnamaldehyde & Flavor and Perfumery agent \\
\hline Quercetin & Mental performance or cardiovascular health \\
\hline Quercetin-3-o-alpha-d-xyloside & Potent free-radical scavenger and antioxidant \\
\hline Sesquiterpenoids & Defensive agents or pheromones. \\
\hline Trans-anethole & Antimicrobial,Antifungaland Insecticidal \\
\hline Shikimic acid & Anticoagulant and Antithrombotic \\
\hline Terpinen-4-ol gamma-terpinene & Antibacterial and Antifungal \\
\hline Veranisatins A, B and C & Analgesic \\
\hline
\end{tabular}


star anise usually use with other spice such as fennel seeds, cloves, cinnamon, pepper etc and considered as one of the "Five Chinese Spice", used for its potent taste and spicy flavor ${ }^{25}$. A special spicy ingredient called "Garam masala" is made by the addition of other popular Indian spices with star anise. Vietnamese use this spice as a major ingredient in noodle soup called $\mathrm{ph} ?^{26}$. In soak form, it intensifies and enhances the flavor of coffee. Star anise is a pleasant spice can be used in whole or ground form. The whole form of this spice is usually make use of to flavor tea, coffee, soup, and other liquids conversely in ground form, star anise is strong and can be added directly to foods. In Asian cuisine, star anise use to enhance the flavor of many spicy dishes especially meat, curries, biryani and also used in desserts and beverages ${ }^{27}$.

\section{Medicinal and Pharmacological Properties: Anxiolytic Effects}

Hexane-extract of Illicium verum fruit oil possess strong anxiolytic effects in male ICR mice. It is proposed that this effect is due to the presence of chief constituents transanethole and related compounds trans-â-methylstyrene, propiophenone and 4'-methoxy-propiophenone. Researchers validated and reported structure activity relationship of several constituents of I.verum such as anethole and transanethole. Result of this analysis show that I.verum fruit oil at the dose of $1 \mathrm{iL}$ produce anxiolytic effects in male ICR mice $^{28}$.

\section{Antimicrobial Effects}

Illicium verum hook.f has a strong anti-microbial property. Chemical investigation of this spice reveals that the chief constituent anethole is responsible for antimicrobial activity and this is abundantly present in dried fruit of I.verum. Numerous studies illustrated that the chief constituent of this spice (anethole) effective against many strain of bacteria, yeast and fungal ${ }^{29,30}$. The recent finding disclosed that the volatile oil of I.verum at the dose of $6 \mu l$ inhibited the growth of Fusarium moniliforme bacteria completely. However the extract of this spice show $50 \%$ mycelial zone of inhibition against P.viridicatum and Pencillium citrinum species ${ }^{31}$.

\section{Antioxidant Effects}

Extract of Illicium verum hook ff anticipate natural antioxidant activity. The earlier investigation revealed that rapeseed oil of this spice exhibit excellent activity to inhibit primary and secondary oxidation product, responsible for the ailment result from the oxidative detrioration ${ }^{32}$. It is consider that the antioxidant activity is mainly due to the presence of active constituent specifically anethole more than $80 \%$ in this spice ${ }^{33}$.

\section{Chemopreventive Effects}

Illicium verum contain prenyl moiety "phenylpropanoids" accountable to inhibit the growth of tumor cell and significantly role as a chemopreventive agent. Experimental
Studies revealed that isolated compound of I.verum show excellent activity against Epestin barr virus early antigen (EBV-EA) at $1 \times 10 \mathrm{~mol}$ ratio and this inhibitory effects is more than ?-carotene ${ }^{34,35}$.

\section{Insecticidal Effects}

The fruit extract of I.verum also possess insecticidal activities due to the presence of phenylpropene, (E)-anethole. Insecticidal activity against B.germanica species were assess by chang and Ahn in $2002^{36}$. This spice is well-known to inhibit and restrain the growth of pest and used to control the progression of various types of insect species. Studies reveal that I. verum fruit extract is highly effective against ?.germenica.

\section{Antiflu Effects}

Star anise is utilized to yield shikimic acid industrially ${ }^{37}$, a principal component to produce the antiflu medicine, Tamiflu $^{38}$. The rigorousness of bird flu virus strain H5N1 were completely diminish by the use of drug Tamiflu. Nowadays, the avian flue ( bird flu) is controlled and treated by commercially available drug Tamiflu ${ }^{39}$.

\section{Atherogenesis Effects}

Treatment with I. verum reduce immunoreactivity of iNOS activation and decrease aortic atherosclerotic plaque lesions and cytokines was observed in ApoE-/- mice. Analyses reveal that the Illicium verum at the dose of $10 \times 100 \mathrm{ug} / \mathrm{ml}$ reduce transcriptional activity of NF-êB in a dose-dependent manner $^{40}$. Furthermore, from the investigation it is revealed that I.verum deteriorated the manifestation of linkage molecules that are responsible for inflammation in these cells. In experimental studiesin HFD-fed APoE-/-mice administration of I.verum or atorvastatin drug depicted the characterstics changes in blood pressure body weight and lipid level ${ }^{41}$.

\section{Lactagouge Effects}

Studies indicated that the dietary supplementation of Illicium verum has beneficial effects, improving lactation performance during gestation and lactation in sows. The diet of this spice increases the concentration of prolactin and IGF-1(insulin like growth factor -1) in milk of sows ${ }^{42}$.

\section{Anticolic Effects}

Anticolic and antidiarrheal effect is also effectively treated by this spice star anise. Recently this study was carried out on mice. In this study percentage of advance activated carbon administered and animal intestinal tract was measured. Diarrhea was inducing by castor oil administration. Orally administration of this spice at different doses 10, 20, 40, and $80 \mathrm{mg} / \mathrm{kg}$ was given ${ }^{43}$. The results of studies shown that this spice decrease activated carbon percentage, responsible for delaying the diarrhea also reduce the number of evacuations as compared to the control group. Investigation depict that the combination of chamomile and star anise produce strong antidiarrheal effects. 


\section{CONCLUSIONS:}

The health benefit of the strong-tasting spice star anise are being progressively recognized and experimentally validated in recent decades. The most studied beneficial pharmacological action of star anise and its active constituents include antimicrobial, antifungal, insecticidal, anticolic, antitumorgenic and anticancer effects. This spice is also a good anxiolytic property and used to prepare antiflu drug. Latterly, Chinese star anise (Illicium verum hook.f) declare tremendous work and play a functional food among all spices and considered as the natural component of our diet, beyond its role in revealing taste and flavor to our food.

\section{REFRENCES:}

1. Ho SH, MA Y,Goh PM. Star anise, Illicium verum hook.f as a potential grain protectant against Tribolium castaneum (Herbst) and Sitophilus zeamais Motsch.Postharvest Biol Technol.1995;6:341-47.

2. Peng W, Lin Z, Wang L. Molecular characteristics of Illicium verum extractives to activate acquired immune response. Saudi J Biol Sci. 2016; 23: 348-52.

3. Yang J F, Yang C H, Chang H W. Chemical composition and antibacterial activities of Illicium verum against Antibiotic resistant pathogens. J Med Food.2010;13(5):1254-62.

4. Wang $\mathrm{G}, \mathrm{Hu} \mathrm{W}$, Huang B, Illicium verum: A reviewon its botany,traditional use, chemistry and pharmacology. J Ethanopharm.2011; 136:10-20.

5. Rocha L, Candido Tietbohl LA. Star anise (Illicium verum hook) oil in essential oils in food preservation. Flav\& safety. 2015; 751-56.

6. Balandrin MF, Kinghorn AD, Farnsworth NR, Plant derived natural products in drug discovery and development.Acs Symp Ser. 1993; 534: 2-12.

7. George CK. Star anise.In: Handbook of Herbs and spices. 2012; 487-03.

8. YounWoo L, YounYong L. Flavor and aroma substances. Food Sci Technol Ser 128 2003; 305-27.

9. Anise S. Star Anise. 2008; 319-330.

10. Sabucedo AJ, Gutierrez MA, Communication M. Chemical composition of Chinese Star Anise. 2014; 4-5.

11. Chempakam B, Balaji S. Star Anise. Chem Spices 2008; 319-30.

12. Bi, Xinyan. Soong YY, Lim, Siang Wee. Henry CJ.Evaluvation of antioxidant capacity of Chinese five spice ingredient.Int j Food Sci Nut. 2015;66(3):289-92.

13. Bukowski J, Mortia C, Berner M. Human ãä T cells recognize alkylamines derived from microbes, edible plants and tea.1999;11(1):57-65.

14. Cai M, Luo Y, Chen J, Liang H.Optimization and comparison of ultrasound assisted extraction and microwave assisted extraction of Shikimic acid from Chinese star anise. Sep Pur Technol. 2014; 133:375-79.

15. Geroge Ck. Star anise.Hand book of herb and spice. 2004; 2(2):10-15.

16. Ahmad AF, Youssef MSH. Chemical composition and bioactive properties of Illicium verum (star-anise) extracts Prepared by different methods. J Sci J.Chem Bio Phy Sci Sec A. 2015; 55 (22): $1160-70$.
17. Wei L, Hua R, Li M. Chemical Composition and Biological Activity of Star Anise Illicium verum Extracts Against Maize Weevil, Sitophilus zeamais Adults. J Insect Sci.2014; 14: 80.

18. Rocha L, Candido Tietbohl LA.Star anise (Illicium verum Hook) Oils. In: Essential Oils in Food Preservation. Flavor and Safety.2016; 85:751-756.

19. Aly SE, Sabry BA, Shaheen MS. Assessment of antimycotoxigenic and antioxidant activity of star anise (Illicium verum) in vitro.J saud soci Agr sci.2016;15:20-27.

20. Kanatt SR, Chawla SP, Sharma A. Antioxidant and radioprotective activities of lemon grass and star anise extracts. Food Biosci. 2014; 6: 24-30.

21. Attokaran M.Star Anise. Nat Food Flavor Color. 2011;91: 365-67.

22. Wisniewski-Rebecca ES, Rocha BA, Wiirzler LAM. Synergistic effects of anethole and ibuprofen in acute inflammatory response. Chem Biol Interact. 2015;1:2-33.

23. Lee R, Balick MJ. Flu for You? The Common Cold, Influenza, and Traditional Medicine. Explor J Sci Heal. 2006; 2: 252-255.

24. Singh G, Maurya S, DeLampasona MP. Chemical constituents, antimicrobial investigations and antioxidative potential of volatile oil and acetone extract of star anise fruits. J Sci Food Agric. 2006; 86: 111-121.

25. Wei L, Hua R, Li M. Chemical Composition and Biological Activity of Star Anise Illicium verum Extracts Against Maize Weevil, Sitophilus zeamais Adults. J Insect Sci. 2014; 14: $1-13$.

26. Lee K, Morris-natschke S, Qian K. Recent Progress of Research on Herbal Products Used in Traditional Chinese Medicine? the Herbs belonging to The Divine Husbandman 's Herbal Foundation Canon ( Shén Nóng Bìn Cao Jîng ). Medicine (Baltimore) 2011; 2: 6-26.

27. Wen K-C, Huang C-Y, Lu F-L. Determination of baicalin and puerarin in traditional Chinese medicinal preparations by high-performance liquid chromatography. J Chromatogr A 1993; 631: 241-250.

28. Wu R. Aromatic plant materials in Chinese foods and beverages. Food Rev Int 1991; 7: 417-443.

29. Putiyanan S, Okonogi S, Charoensup W. Pharmacognostic characterization of Illicium verum hook. f. for dental application. Chiang Mai Univ J Nat Sci. 2010; 9: 89-94.

30. Miyagawa M, SatouT,Yukimun C.Anxiolytic like effects of Illicium verum fruit oil transanethole and related compound in mice. Phyther Res.2014; 28:1710-12.

31. Hung Y, Zhao J, Zho L. Antifungal activity of the essential oil of Illicium verum and its main component transanethole. Molecul.2010; 15:7558-69.

32. Dzamic A, Sokovic M, Ristic M. Chemical compositionand antifungal activity of Illicium verum and Eugenia caryopllata eseential oil.Chem Net Comp.2009;45:259-61.

33. De M, De AK, Sen P. Antimicrobial properties of Star anise (Illicium verum Hook f). Phyther Res 2002; 16: 94-95.

34. Bi, Xinyan. Soong YY, Lim, Siang Wee. Henry CJ. Evaluation of antioxidant capacity of Chinese five-spice ingredients. Int J Food Sci Nutr 2015; 66: 289-292.

35. Aazza S, Lyoussi B, Miguel MG. Antioxidant and Antiacetylcholinesterase Activities of Some Commercial Essential Oils and Their Major Compounds.Molecule. 2011; 7672-7690. 
36. Itoigawa $\mathrm{M}$, Ito $\mathrm{C}$, Tokuda $\mathrm{H}$. Cancer chemopreventive activity of phenylpropanoids and phytoquinoids from Illicium plants. Cancer Lett 2004; 214: 165-169.

37. Chen $\mathrm{CH}$, DeGraffenried LA. Anethole suppressed cell survival and induced apoptosis in human breast cancer cells independent of estrogen receptor status. Phytomedicine. 2012; 19: 763-767.

38. Park CG, Shin E, Kim J. Insecticidal activities of essential oils, Gaultheria fragrantissima and Illicium verum, their components and analogs against Callosobruchus chinensis adults. J Asia Pac Entomol. 2016; 19: 269-273.

39. Chen X, Yuan L, Wei L. Content Analysis of Shikimic Acid in the Masson Pine Needles and Antiplatelet- aggregating Activity. IJAST.2014; 2: 110-114.

40. Khan TM. Use of star anise tea in swine flue prevention and safety concerns. Complement Ther Clin Pract 2010; 16: 175.

41. Rabelo TK, Zeidán-Chuliá F, Caregnato FF, et al. In Vitro
Neuroprotective Effect of Shikimic Acid Against Hydrogen Peroxide-Induced Oxidative Stress. J Mol Neurosci 2015; 56: 956-965.

42. Park SH, Sung Y-Y, Nho KJ, et al. Protective activity ethanol extract of the fruits of Illicium verum against atherogenesis in apolipoprotein E knockout mice. BMC Complement Altern Med 2015; 15: 232.

43. Kang P, Kim KY, Lee HS, et al. Anti-inflammatory effects of anethole in lipopolysaccharide-induced acute lung injury in mice. Life Sci 2013; 93: 955-961.

44. Wang GY, Yang C, Yang Z, et al. Effects of dietary star anise (Illicium verum hook $\mathrm{f}$ ) supplementation during gestation and lactation on the performance of lactating multiparous sows and nursing piglets. Anim Sci J 2015; 86: 401-407.

45. Diaza A, Vargas-Perez I, Aguilar-Cruz L. A mixture of chamomile and star anise has anti-motility and antidiarrheal activities in mice. Brazilian J Pharmacogn.2014; 24: 419-424. 